\title{
C VMによる新潟海岸の環境整備便益の計測 \\ CVM ESTIMATION OF THE BENEFIT OF BEACH PRESERVATION FROM ENVIRONMENTAL ASPECTS
}

\author{
今村能之 ${ }^{1} \cdot$ 佐藤壃司 $^{2} \cdot$ 笠井雅広 $^{3} \cdot$ 齋藤明 $^{4} \cdot$ 原文宏 $^{5} \cdot$ 平野宜一 $^{6}$ \\ Yoshiyuki IMAMURA, Shinji SATO, Masahiro KASAI, Akira SAITO, \\ Fumihiro HARA, Giichi HIRANO \\ ${ }^{1}$ 正会員 工修 建設省河川局河川計画課( \\ ${ }^{2}$ 正会員 工博 前 建設省土木研究所河川部海岸研究室 $(\overline{7} 305-0804$ 茨城県つくば市大字旭 1 ) \\ ${ }^{3}$ 正会員 工修 建設省土木研究所河川部海岸研究室(テ305-0804 茨城県つくば市大字旭 1 ) \\ ${ }^{4}$ 建設省北陸地方建設局河川部河川計画課(广951-8505 新潟県新潟市白山浦 1-425-2) \\ ${ }^{5}$ 正会員 (㑣建設技術研究所海岸海洋開発室( $(\bar{T} 103-8430$ 東京都中央区日本橋本町 4-9-11)

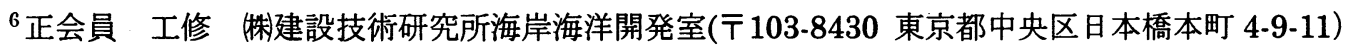

The benefit of beach preservation at Niigata coast was estimated by the Contingent Valuation Method. Estimation was performed from the environmental aspect on the beach recovery efforts of Niigata coast by shore protection works. The result was correlated with various properties, such as age, sex, annual income and the distance of the residence from the coast. It was found that median value of 1,591 yen/year can be afforded for the maintenance of the present beach environment for the use of recreational purposes. High correlation was found between the interest on beach preservation and the frequency of visit to the beach.

Key Words: cost-benefit analysis, coastal environment, Contingent Valuation Method, shore protection works

\section{1.はじめに}

海岸事業は、国土保全および環境整備（適正な海 岸利用と自然環境保全)の観点から実施されている。 国土保全効果とは、高潮・津波・侵食等の災害加 物的・人的被害や精神的被害を軽减する効果であり、 環境整備効果とは、砂浜の確保や海岸へのアクセス 性向上等の海岸整備によるレクリエーション等の利 用促進効果や、水質 - 生態系 - 景観等の自然環境保 全効果である。

近年、公共事業の透明性・客観性の確保の観点か ら、事業実施に際し費用便益分析が行われている。
海岸事業における費用便益分析においては、高潮・ 侵食対策による物的被害軽减便益のみを評価対象と してきた。しかし、実際に何らかの目的で事業が実 施された場合、先に述べた様々な便益が複合的に発 生する事が考えられるため、費用便益分析において は、便益の二重計測に注意しながら、これらを総合 的に評価するのが適切である。

環境整備による利用促進便益や自然環境保全便益 はそれらが非市場財であるため、便益評価には留意 が必要である。一般に非市場財の便益計測法として は以下の示す 3 つが挙げられる ${ }^{1), 2), 3) 。 ~}$

・旅行費用法 (TCM) 

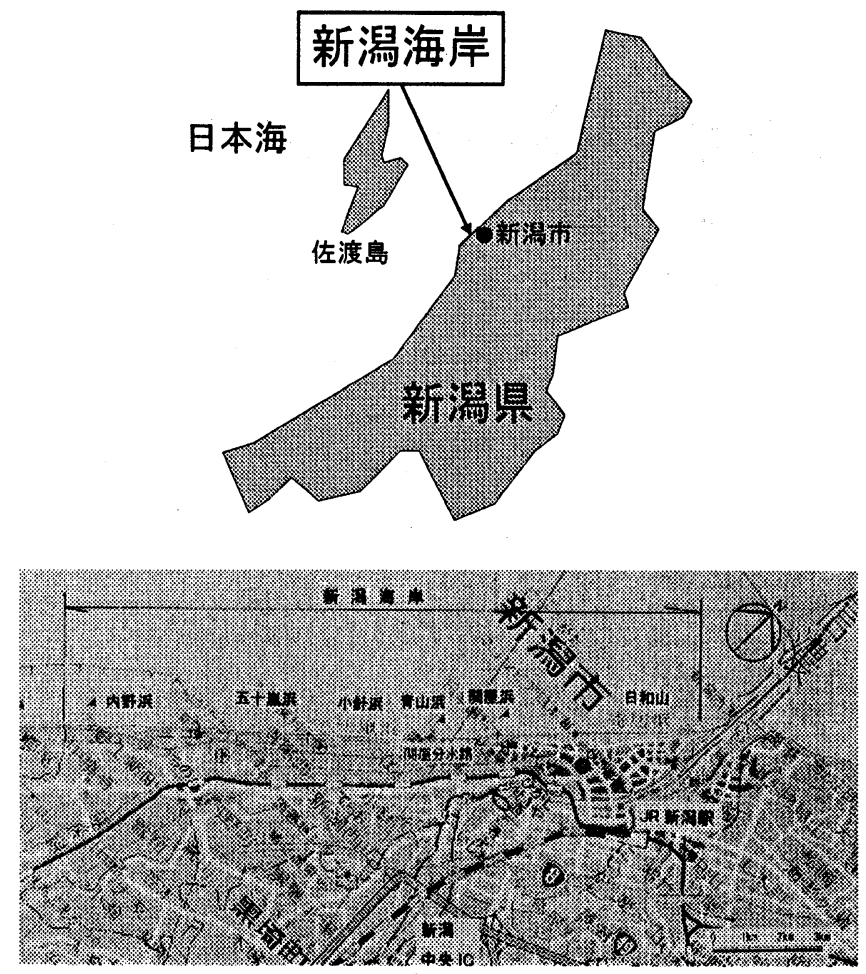

図-1＼cjkstart対象海岸位置図

写真-1 離岸堤背後の堆砂状況(小針浜付近)

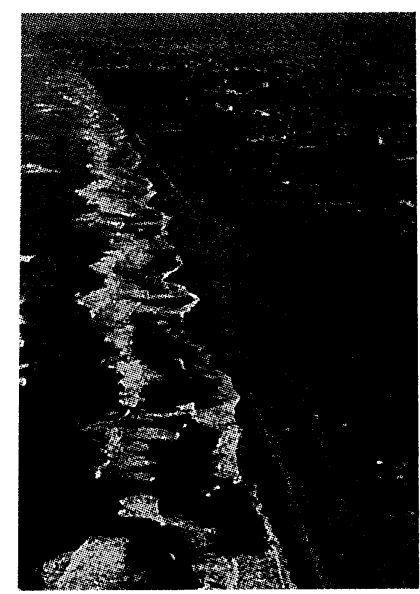

(昭和 52 年)

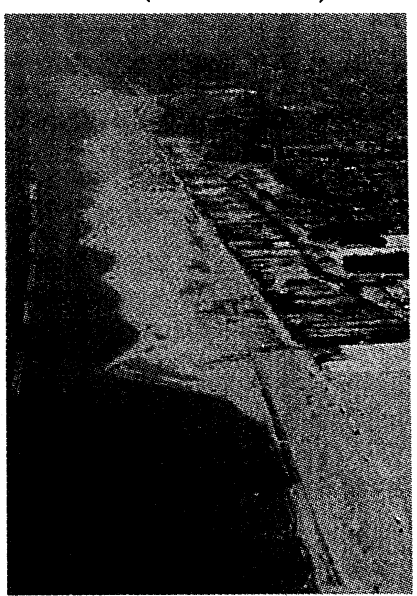

(現在)
・ヘドニック価格法（HPM）

・仮想金銭化法 (CVM)

このうち、旅行費用法については利用者がなぜ他 の場所でなくその海岸を利用するかといった選択行 動を設定する際に膨大なデータが必要となる。また、 ヘドニック価格法については沿岸域での適切な地価 データの入手が困難である、といった問題点を有し ている。本研究では、適用範囲の広い CVM を用い、 海岸事業による利用促進等の環境整備便益計測手法 を検討し、ケーススタデイによりその適用性を検討 した。

\section{2. 調査内容}

表-1 CVM 調查票(設問部分)

新潟海岸で様々なり归エーションや教育、健康增進の場として利 用できるように砂浜を復活・維持していくためには、構造物 の設置や維持に費用がかかります。そこで、新潟海岸の砂浜 維持を目的とした基金を設置するとします。

ここでの基金は新潟海岸のみに使われ、新潟海岸以外の海 岸に対しては一切使われません。ただし、砂浜の復活・維持 のための作業は他地域の企業によってなされるとします。

\begin{tabular}{|c|c|}
\hline 基金ができた場合 & $\begin{array}{l}\text { 現在から } 2028 \text { 年までの } 30 \text { 年間、現 } \\
\text { 在ある砂浜は維持され、いつでも自 } \\
\text { 由に様々な利用ができます。 }\end{array}$ \\
\hline $\begin{array}{l}\text { 基金ができなかっ } \\
\text { た場合 }\end{array}$ & $\begin{array}{l}\text { 現在から } 10 \text { 年後( } 2008 \text { 年)まで砂浜 } \\
\text { は現在の状態ですが、離岸堤は維持・ } \\
\text { 管理できないため、それ降大きな } \\
\text { 波がきた時には離岸堤が壊れ、再び } \\
\text { 青山浜や小針浜の砂浜は失われてま } \\
\text { す。そして、 } 30 \text { 年後(2028 年)には砂 } \\
\text { 浜が現在より } 40 \mathrm{~m} \text { 近く後退すると仮 } \\
\text { 定してください。 }\end{array}$ \\
\hline
\end{tabular}

もし、このような砂浜維持の基金が設置された場合、この基 金に対して、あなたは 30 年の間、一世帯あたり毎年 円 の寄付をしてもよいと思いますか。

当然、奇付した場合、家計の所得はその分だけ減ることを 十分お考えください。

\section{(1) 対象海岸}

調査対象は図-1 に示す日本海沿岸の新潟海岸と した。新潟海岸は、信濃川河口の西側約 $20 \mathrm{~km}$ の砂 浜海岸で、古くから「白砂青松」の海岸として知ら れていた。しかしながら、陸域の総合的な開発や信 濃川の改修(大河津分水、関谷分水)、大規模な沿岸 構造物の建設、地盤沈下等の複合的な影響により、 著しい海岸侵食が生じた。このため昭和 52 年より 侵食の著しい区間については、離岸堤・人エリーフ 等の整備による侵食対策事業が行われ、砂浜が確保 されてきた。写真-1 は海岸保全施設施工前(昭和 52 年)と施工後(現在)の新潟海岸小針浜付近の航空写真 であるが、離岸堤の背後には砂の堆積が見られる。 近年は、海浜公園、道路、緩傾斜護岸などの整備が なされ、レクリエーション等、多様な利用がなされ ており、海岸事業における環境整備便益を検討する 上で適当な海岸であると考えた。

\section{(2) $C \vee M$ 調查の概要}

新潟海岸における侵食対策事業による物的被害軽 減便益については、事業が行われなかった場合の侵 食想定区域の資産を積み上げる方法で評価がなされ 
表-2 2 段階 2 項選択方式の提示金額

\begin{tabular}{|c|c|c|c|}
\hline & 1 回目 & 2 回目(Yes) & 2 回目(No) \\
\hline 1 & 500 & 1,000 & 300 \\
\hline 2 & 1,000 & 2,000 & 500 \\
\hline 3 & 2,000 & 3,000 & 1,000 \\
\hline 4 & 3,000 & 5,000 & 2,000 \\
\hline 5 & 5,000 & 7,000 & 3,000 \\
\hline 6 & 7,000 & 10,000 & 5,000 \\
\hline
\end{tabular}

(単位:円/年/世帯)

表-3 回答者内訳

\begin{tabular}{|c|r|r|r|}
\hline 年齢 & \multicolumn{1}{|c|}{ 男性 } & \multicolumn{1}{|c|}{ 女性 } & \multicolumn{1}{c|}{ 計 } \\
\hline 20 歳代 & 9 & 10 & 19 \\
\hline 30 歳代 & 15 & 19 & 34 \\
\hline 40 歳代 & 34 & 28 & 62 \\
\hline 50 歳代 & 24 & 19 & 43 \\
\hline 60 歳代 & 35 & 19 & 54 \\
\hline 70 歳代 & 20 & 8 & 28 \\
\hline 計 & 137 & 103 & 240 \\
\hline
\end{tabular}

ている ${ }^{4)}$ 。一方、侵食対策による砂浜の確保や周辺 環境の整備による利用および自然環境保全便益(環 境整備便益)についてはこれまで評価がなされてい なかった。そこで CVM により新潟海岸の環境整備 便益を計測することを試みた。

\section{a) 現状説明}

CVM 調查票ではまず新潟海岸の概要、位置を示 した後、新潟海岸における海岸の利用の現状を具体 的に示した。ここでは、「海水浴」、「散策」、「釣り小、

「パラセイリング」、「ダイビング」等、砂浜・空中 · 海中のレクリエーション利用状況を説明し、「景観 鑑賞」、「健康増進」、環境教育」等、その他の多様 な利用が可能であることを説明した。

次に海岸侵食の経緯と対策事業の概要を説明した。 侵食およびその対策の説明は中立的な立場からの説 明となるよう留意し、海岸全体では構造物により砂 が堆積している箇所もあれば、その下手では侵食し ている箇所もあることを付け加えた。

\section{b）仮想市場}

表-1 に CVM 調査票の設問部分を示す。a)の説明 の後、仮想市場として、利用環境を今後も維持して いくために基金を設置することとし、今後 30 年間、 基金への寄付金をもとに砂浜維持等の利用環境整備 を行っていくことを仮定した。ただし、基金が設置 された場合には、海岸事業費分に相当する税金は負 担する必要がなくなることとした。そして、基金が 設置された場合には、現在のような利用環境が維持 されていくこと、基金が設置されなければ、砂浜の 維持等ができなくなり、海岸利用に影響が出るとい
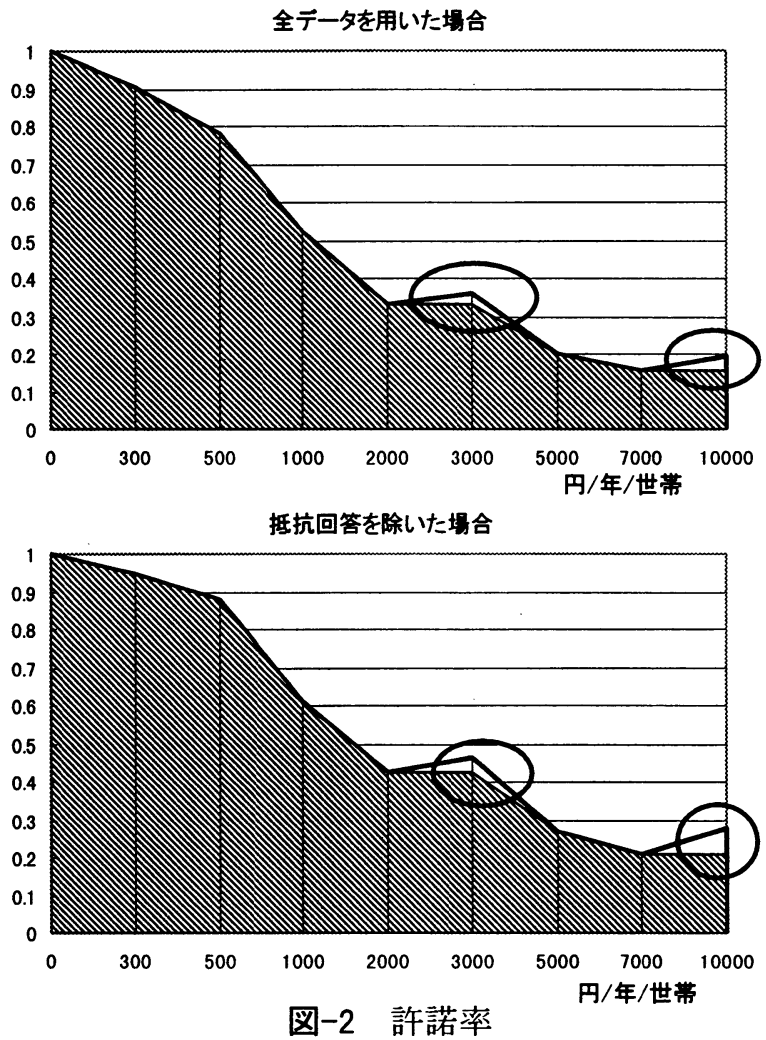

う仮定を写真を用いて説明し、今後 30 年間ひ基金 に対する一世帯あたりの支払い意志額を問うことに した。

支払い方法については、一般に「税金」「基金小、 「入場料」などがあるが、税金は抵抗回答が大きく なる、入場料は母集団への拡大（総便益の算定）が 難しい等の問題が考えられたため、今回は基金を設 置して寄付を募るという形式を取った。表-1 の説 明の中で「作業は他地域の企業によってなされる」 としたが、これはフロー効果を期待して回答しない こと（地元にお金が落ちる等本来の価値とは違うも のに対する回答）に留意したものである。また、寄 付金は新潟海岸以外の海岸に対しては一切使われな いことも明記した。

\section{c）支払い意志額の回答方法}

支払い意志額の回答方法には「自由記入方式小 「支払カード方式小「2 段階 2 項選択方式」がある が、既往の事例でバイアスが最も少ないとされる「2 段階 2 項選択方式」とした ${ }^{2)}$ 。

表-2 に、今回の調査における 2 段階 2 項方式の 提示金額を示す。この方式では、被験者をランダム に 6 つのグループに分け、例えばグループ 1 の被験 者に対しては、シナリオを説明したのち、それに対 して「500 円/年/世帯」の支払いに応じてもらえる かを Yes、No で回答してもらい、Yes の人にはさ 
らに「1,000 円/年/世帯」、No の人には「300 円/年/ 世帯」を提示して、再度支払い意志を Yes、No で 回答してもらう。つまり 1 人の被験者は 2 回金額を 提示され、それぞれについて支払い意志をYes、No で回答する事になる。提示金額の大きさ、段階設定 については、事前に 20 人程度の人に「自由記入方 式」による調查を実施して決定した。

\section{（3）調查方法}

調査対象の母集団は新潟海岸に面し、新潟海岸を 利用する人が最も多い新潟市とした。サンプリング は 2 段階抽出による住民基本台帳からのランダムサ ンプリングとした。サンプル数は計 300 とし、原 則的に被験者は世帯主とした。調査はすべて面接方 式で実施した。

調査は、平成 10 年 8 月 7 日〜 8 月 24 日にかけ て実施し、配布数 300 に対して、回答数 240 (回収 率 80\%）を得た。回答者の属性を表-3 に示す。性 別は女性より男性の方が若干多く、年齢は 40 歳代、 60 歳代が多い。

\section{3. 支払意志額の推定}

支払意志額は、(1)すべてのデータを用いた場合、 (2)寄付行為に対する抵抗回答を除いた場合、の 2 ケースについて、それぞれ、中央值および平均值を 算定した。算定はノンパラメトリック推定法により、 それぞれの金額を提示されて「Yes」と回答した人 の割合 (許諾率) を求め、中央值と平均値を推定し た。集計した許諾率を図-2 に示す。ある金額の許 諾率がそれより低い金額の許諾率を上回った場合に は、その金額の許諾率を一段階低い金額の許諾率に 置き換えて使用した(図-2 中の○印)。平均值はグ ラフの斜線部分の面積であり、中央值はY軸の 0.5 の線とグラフの交わった点の X軸の金額である。表 -4 に新潟海岸の環境整備便益に対する支払意志額 の推定結果を示す。

\section{4. 調査結果の分析}

精度の良い CVM 調查を実施するためには、被験 者がシナリオを十分に理解した上で、それに対する 支払い意志額の回答を得ることが重要である。その ためには説明が専門的すぎない、長すぎないなどの
表-4 推定した支払意志額

\begin{tabular}{|l|r|r|r|}
\hline & \multirow{2}{*}{ 中央値 } & \multicolumn{2}{|c|}{ 平均值 } \\
\cline { 3 - 4 } & & $\begin{array}{c}\text { 頭切り } \\
10,000 \text { 円 }\end{array}$ & $\begin{array}{c}\text { 頭切り } \\
7,000 \text { 円 }\end{array}$ \\
\hline 全データを用いた場合 & 1,110 & 2,906 & 2,434 \\
\hline 抵抗回答を除いた場合 & 1,591 & 3,584 & 2,953 \\
\hline
\end{tabular}

(単位 : 円/年/世帯)

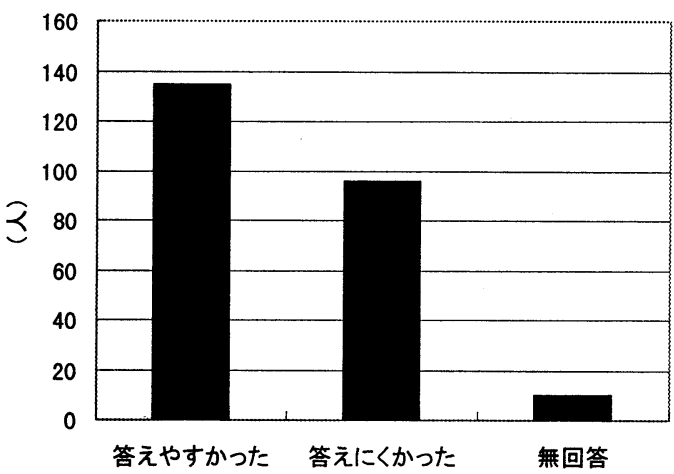

図-3アンケート票の答えやすさ

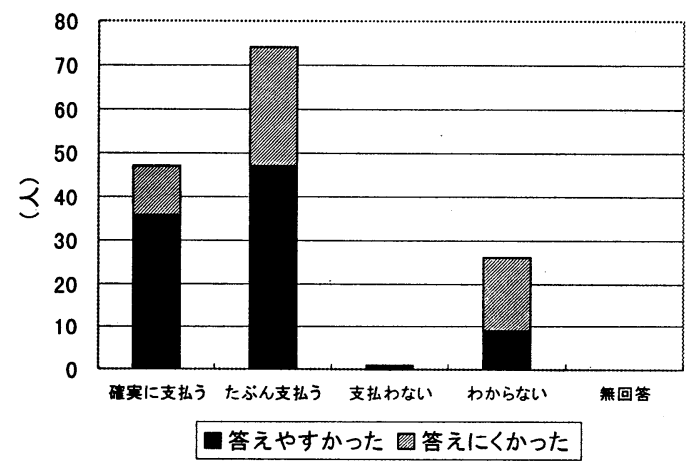

図-4「本当に支払うか」と「答えやすさ」の関係

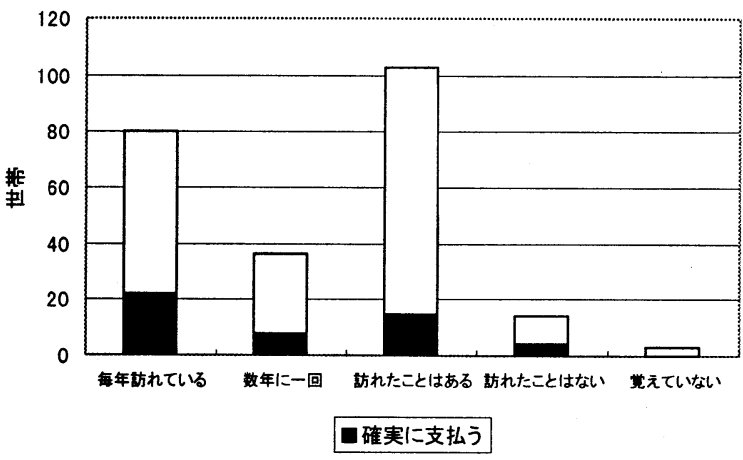

図-5 訪問回数と「確実に支払う」の関係

留意が必要である。図-3 にアンケート票が「答え やすかったか」との質問に対する回答を示した。「答 えやすかった」と回答した人の方が多く、全体で $56 \%$ となっている。また、「実際に基金が設置された場 合本当に回答金額を支払うか」との質問に対する回 答と「答えやすかったか」との質問に対する回答の 関係を図-4 示す。「確実に支払う」と回答した 47 人のうち $76 \%$ にたる 36 人が「答えやすかった」 と回答した。この結果から「答えやすい（わかりや 
すい)」アンケートの作成が重要であることがわか る。「確実に支払う」と回答した人とそうでない人 に新潟海岸に対してどのような意識の違いがあるか を把握するため、「新潟海岸への訪問回数」との関 係を示したものが図-5 である。毎年訪れている人 が「確実に支払う」と回答する割合が最も多くなっ ている。しかし、訪れたことがない人が「確実に支 払う」と回答する場合もある。これは被験者本人の 実利用が伴わない場合でも、オプション価値に対す る支払い意志を反映しているものと考えられる。

図-6に「新潟海岸の砂浜の復活・維持に関心が あるかどうか」との質問の回答と「確実に支払う」 との関係を示す。「新潟海岸の砂浜の復活・維持に 関心がある」とする人が「確実に支払う」と回答す る割合は「多少関心がある」、「わからない」と比較 してかなり大くなっており、関心の程度に比例して いると考えられる。

図-7 に新潟海岸の砂浜の復活・維持に関心があ る人の数を年代別に示す。「関心がある」と回答し た人の $93 \%$ 「40 歳代以上」となっている。この 結果をみると、20、30 歳代は新潟海岸の砂浜が復 活・維持されることにそれほど強い関心をもってい ないとも受け取れる。しかし、近年の新潟海岸しか 知らない人は、離岸堤の設置によって汀線が前進す る又は現状の新潟海岸しか見ておらず、昔のような 広大な砂浜があってそれが大きく侵食したことをよ く知らないため、砂浜を復活・維持することには強 く関心をもっていない可能性もある。

\section{5. 海岸と居住地との距離による意識の 違い}

海岸と居住地との距離による支払意志額の違い （支払意志額の距離減衰）を調べるため、居住地と 海岸の距離に応じて被験者を 3 グループに分け、そ れぞれに付いて支払い意志額を算定した。分類条件 は次のとおりとした。

・海岸から 0～2km（サンプル数 : 137）

・海岸から 2〜4km （サンプル数 : 56）

・海岸から $4 \mathrm{~km}$ 以上 (サンプル数 : 60 )

ここで、居住地および支払い意志額が所得と相関が ある可能性があるため、上記の各グループの平均所 得を調べたが、 3 グループともほぼ同額であった。 そこで、居住地と所得とは相関がないとの前提のも

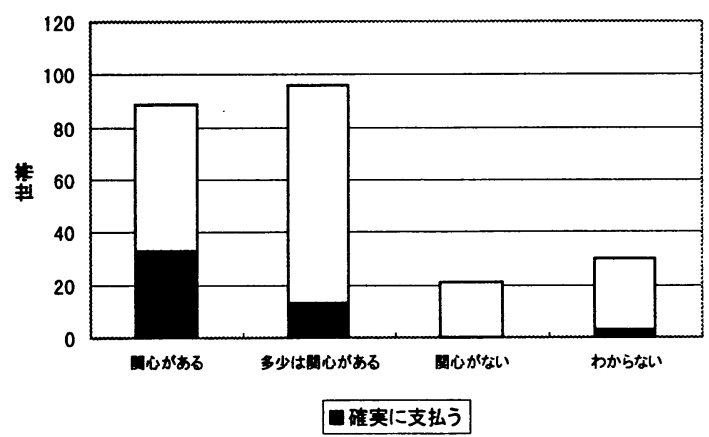

図-6＼cjkstart新潟海岸の砂浜が昔のように復活・ 維持されることに関心があるか

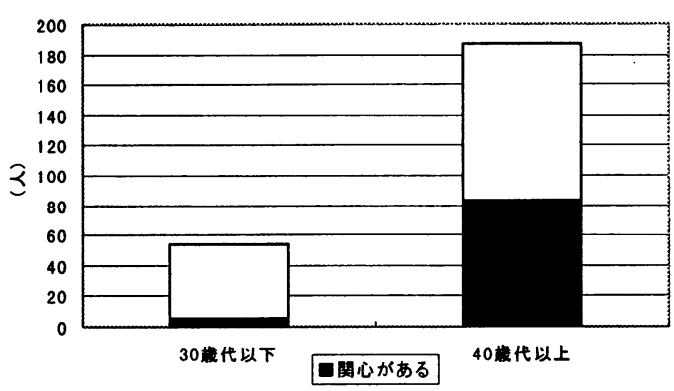

図-7 年代別新潟海岸で砂浜の復活・ 維持に関心がある人

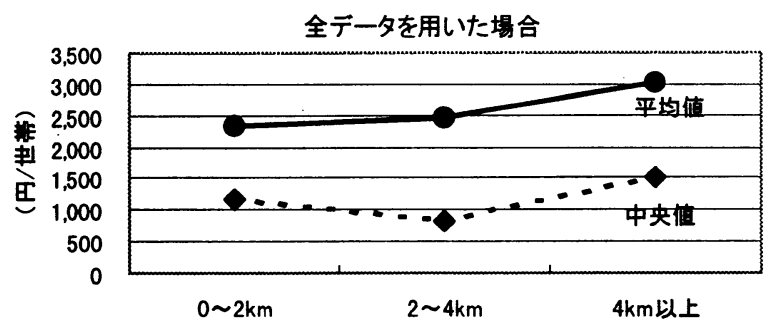

「確实に支払う」を用いた坦合

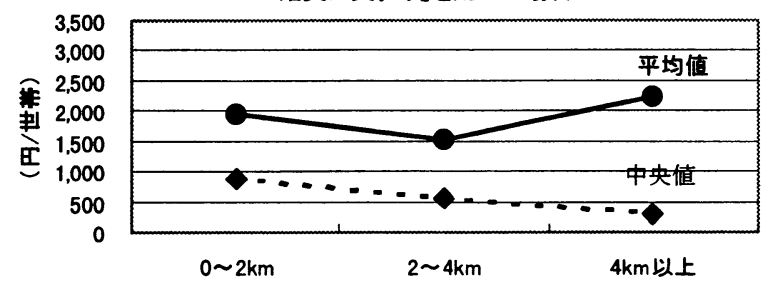

海岸と居住地間の距離

図-8＼cjkstart海岸と居住地の距離による支払意志額 の違い

とに各グループについて、以下の条件で支払い意志 額を推定した。

・全データを用いた場合

・「確実に支払う」を用いた場合

図-8に推定した支払意志額を示す。新潟市は海 岸に沿って細長く、内陸方向へは海岸から $10 \mathrm{~km}$ 程 度である。したがって、各支払意志額の平均値をみ ても、新潟市内では明確な距離减衰は生じておらず、 利用便益の及ぶ範囲は新潟市内だけでなく、さらに 
内陸側まであると考えられる。ただし、「確実に支 払う」を用いて算定した中央值は、距離によって支 払意志額が減衰していく傾向がみられる。中央值は 半数の人の代表意見ということを考慮すると、平均 值よりも距離による意識の違いが表れやすいと考え られ、実際には多少の距離减衰は生じている。

サンプル数が少なく支払意志額の推定はできなか ったが、沿岸部 $(0 \sim 2 \mathrm{~km})$ に住んでいる人は「答 えにくかった」と回答した人でも「確実に支払う」 という人が若干名いるが、 $2 \mathrm{~km}$ 以上離れて住んで いる人は「答えにくかった」と回答して「確实に支 払う」という人はほとんどいなくなり、その点にも 海岸からの距離による意識の違いが表れていると考 えられる。

\section{6. まとめ}

新潟海岸を対象として環境整備便益の CVM 調查 を行った。本研究では支払意志額をノンパラメトリ ック推定法により求め、平均值と中央値を推計した。 推計は全てのデータを用いた場合と「寄付行為によ る反対」などの抵抗回答を除いた場合の 2 ケースと して、最高掲示額 10,000 円と統計上の誤差を考慮 した 7,000 円で頭切りを行った。推定された金額は、 次のとおりである。 全データを用いた場合

・中央値 1,110 円/世帯/年

- 平均值 2,906 円/世帯/年（頭切り 10,000 円）

- 平均值 2,434 円/世帯/年（頭切り 7,000 円） 抵抗回答を除いた場合
- 中央值 1,591 円/世帯/年

- 平均值 3,584 円/世帯/年（頭切り 10,000 円）

- 平均值 2,953 円/世帯/年（頭切り 7,000 円）

・平均値 2,953 円/世帯/年 (頭切り 7,000 円)

回答した支払意志額について本当に支払うかどう かについては、新潟海岸への訪問回数、砂浜の復活・ 維持への関心が強く影響を及ぼしていることがわか った。また、海岸からの住んでいる距離による支払 意志額の違いについては、新潟市内程度の狭い領域 ではほとんど生じていないことがわかった。

今後は、今回得られた結果をもとにアンケート票 の修正を図り、サンプル数を増やした精度の高い調 查へと進めていく。また、生態系の保全効果につい ての検討を進めていく予定である。

謝辞 : 本研究の遂行にあたり、東京工業大学社会工 学科肥田野登教授に終始ご指導を頂きました。ここ に記して謝意を表します。

\section{参考文献}

1)植田和弘: 現代経済学入門 環境経済学, 岩波書店, 1996. 2)栗山浩一: 公共事業と環境の価值 - CVM ガイドブッ クー, 築地書館, 1997.

3)肥田野登：環境と社会資本の経済評価 ヘドニック・ アプローチの理論と実際，到草書房，1997.

4)建設省北陸地方建設局: 平成 8 年度 新潟海岸事業経済 効果検討業務委託報告書, 1997 .

(1999.4.19 受付) 